\title{
COMPETITIVENESS AND THE INCREASING STRATEGY OF COMPETITIVENESS IN TOURISM SECTOR OF TERNATE CITY, NORTH MALUKU PROVINCE
}

\author{
MUHARTO \\ A Student of Doctoral's Program in Management Science, Business and Economy Faculty \\ University of Samratulangi Manado, Indonesia, E-mail: muhartolaode@gmail.com

\section{Bernhard TEWAL} \\ Faculty of Economics and Business, Department of Management \\ Sam Ratulangi University of Manado, Indonesia, E-mail: tewalb@yahoo.com

\section{Silvya L. MANDEY} \\ Faculty of Economics and Business, Department of Management \\ Sam Ratulangi University of Manado, Indonesia, E-mail: Silvyamandey@rocketmail.com
}

\author{
Altje TUMBEL \\ Faculty of Economics and Business, Department of Management \\ Sam Ratulangi University of Manado, Indonesia, E-mail: altjetumbel@yahoo.com
}

\begin{abstract}
A tourism sector that has high competitiveness can draw a great number of tourists that can result in well-improved regional economy growth, increasing rate of society's income, and bigger opportunity into the work field. The growth rate of tourist visits in Ternate City from 2011-2015 is increasing, yet its growth percentage is changeable and tends to decrease. This research aimed at: 1) analyzing the competitiveness position of tourism sector of Ternate City against other regions in North Maluku Province; 2) formulating the strategy to increase tourism sector of Ternate City. The data were collected through documentation and interview. The data were obtained from Government Tourism Office, Central Bureau of Statistics, Regional Revenue and Asset Management Office, Development Planning Agency at Regional Level, Environmental Agency and Ministry of Finance of the Republic of Indonesia. The data obtained were analyzed using mix-methods consisting of shift share analysis, indexation, and SWOT.

The result of this research showed that the performance of tourism sector in Ternate City from 2011-2015 had positive growth better than that from North Maluku Province. This contributed to better society's economy and employment absorption in Ternate City. The use of Diamond Porter model helped explain that tourism competitiveness in Ternate City is in the top position surpassing the other regencies/ cities in North Maluku Province. The main factor of its competitiveness is the existence of supporting and related industrial activities such as hotel, inn, man power, restaurant and
\end{abstract}




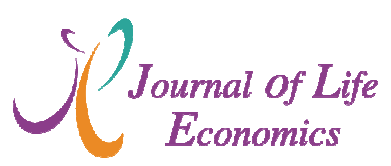

cafe as well as the number of tourist visits. Meanwhile, the less competitive indicators are the number of tourist spots and the regional strategy. Moreover, the government's role was still considered lower than those from North Halmahera, Morotai, West Halmahera, Tidore, and Central Halmahera. Based on SWOT analysis, the strategies that can maintain and increase the tourism competitiveness in Ternate City are: 1) utulization of Information technology to attract domestic and foreign tourists; 2) building up the cooperation system with the surrounding regions in managing the integrated tourism sector; 3) cooperating with the local and central government in developing the tourism sector; 4)empowering tour operators in attracting the tourists; 5) improving the quality and the quantity of scientific and cultural tourism; 6) facilitating the tourists to enter the tourist destination area.

Key word: Competitive Advantage, Diamond Theory, Tourism Sector Index, Strategy, Ternate JEL Codes: J20, J21, O11, R11, Z30

\section{INTRODUCTION}

Tourism sector affects nation's development. In economy aspect, tourism is seen as a rapidly growing industry which even becomes the top driver of economy growth and arouses multiplier effect to the other sectors (WTO, 2002; Othman dan Mohd, 2011; Kovačić, et al 2011; Guzmán, et al 2011; Karini, 2011; Wu dan Chang, 2013; Aryunda, 2011). It also decreases poverty and regional disparity in the developing countries (Chin, 2011). From socioclutural aspect, tourism becomes social solidarity trigger and improves fellowship among nations (Hamarneh, 2013), culture preservation and historical value appreciation (Suardana, 2011). From environmental aspect, tourism encourages conservation movement and love act to protect the environment (Prayogi, 2011).

At the global level, tourism accounts for 5\% (USD 1.4 trillion) of global exports and $9.5 \%$ of the world's total GDP. While nationally, the strategic role of tourism is reflected on the solid contribution given to the national economy even when the performance slowdown occurs in almost all sectors (Bank Indonesia, 2015: 82). The largest economy impact of the tourism sector occurs on employment of $9.00 \%$ of national employment in 2014 or about 10.32 million people residing in tourism-related sectors (Kemenpar, 2014: 32).

In Indonesia, the national tourism performance shows a fairly good development, especially in the last five years, both related to the visits of foreign tourists (wisman) and domestic tourists (wisnus). The number of foreign tourists increased continuously throughout 2009-2014 with an average increase about $7.2 \%$ per year, higher than the world average of only $4.7 \%$. The rising number of foreign tourist visits is accompanied by an increase in foreign exchange earnings of an average $12.23 \%$ per year. In 2014 the number of foreign tourists was 9.44 million or grew 5.66\% and generated foreign exchange of US \$ 11.01 billion, an increase of $9.47 \%$ compared to 2013 . This rise positioned tourism as the country's largest foreign exchange earner, in the fourth rank after oil \& gas, coal, and palm oil (Kemenpar, 2014: 52).

The publication of the Word Ecomic Forum (WEF) in 2011, 2013 and 2015 on The Travel \& Tourism Competitiveness Index Report showed an increase in the competitiveness of national tourism, in which in 2011 Indonesia was ranked 74 out of 140 countries, ranked 70 in 2013 and ranked 50 in 2015. Although Indonesia's tourism competitiveness rating has improved compared to the previous year's position, it has not made Indonesia change to a better position relatively to Singapore, China, Malaysia, and Thailand. Based on World Travel and Tourism Council (WTTC) Report in 2008 and WEF in 2015 on Tourism \& Travel Competitiveness Index (TTCI) it was found that from a number of competitiveness parameters used, only price parameters are the main factors of competitiveness in Indonesia. Crotti and Tiffany (2015: 17) WEF institute analysts point out that Indonesia's 


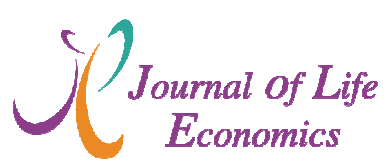

competitiveness weaknesses include: (i) infrastructure; (ii) environmental sustainability protection; (iii) Deforestation; (iv) Hygiene; (v) safety and security.

The tourism development becomes very important in order to increase the national income as well as the regional income in improving people's welfare and prosperity, to expand employment and to encourage regional development. This causes many regions competing one another to introduce their tourism potential in order to attract tourist visits as much as possible. Blanked and Chiesa (2008: 19) revealed that there was a positive correlation between the competitiveness of destination countries with the number of foreign tourists who visited the country or region. In this case, tourism that has the competitiveness can attract tourists to visit the area (Gracan, et al, 2008; Stipanovic, et al, 2008; Jovicic and Vanja, 2008; Meyer, 2012; Wu and Chang, 2013). The competitiveness of a tourism will provide satisfaction for the tourists which in turn form the behavioral loyalty, i.e. visiting a toursit object repeatedly and even inviting others to visit the tourist destination (Valle et al., 2006; Gracan, et al, 2008; Stipanovic, et al, 2008; Jovicic and Vanja, 2008; and Meyer, 2012). However, it cannot be denied that the competitiveness of an industry including the tourism sector is not always durable because it is influenced by internal and external factors or the pressure from competitors (David and David (2015: 43). In fact, tourism activities run in open spaces, while tourist decisions are independent and can change anytime towards the tourist object (Tathagati and Indscript, 2015: 3-4). Balan, et al., (2009) revealed the fact that in 1950 there were 15 top destinations that attracted $98 \%$ or almost all tourists to these destinations, but 60 years later it remained $57 \%$. Croatia's failure in modern tourism competition in the global market of the 21 st century is caused by the less adaptive of its tourism development to the current development and its low innovative effort as well as its tendency to the old paradigm (Stipanovic, et al, 2008). In this case, competitiveness is not only determined by the natural resources or the existing input factors, but the other contributing factors are also influential such as the role of innovation and technological development, the political condition and the consistency of government policies in the regions or countries of tourist destinations (Damanik 2013: 50; Wu and Chang 2013; Othman and Rosli 2011; Chang and Hsia, 2013). The above description was in line with the tourism condition in Ternate, in which in 2012 Ternate City accounted for $83 \%$ of tourism market in North Maluku Province. Two years later, in 2014, the tourism market decreased by $16 \%$ resulted in $67 \%$. The Growth of tourist arrivals deriving from both foreign and domestic tourists in Ternate city fluctuated and tended to decline. Overall, the tourist growth from 2011 to 2015 tended to deteriorate. This indicated the occurrence of some problems especially those regarding to the competitiveness and the competitive strategy which, in turn, made it strongly important to be examined. The movement of tourism competitiveness performance (2011-2015) was analyzed using shift share analysis. The position of tourism competitiveness in 2015 was analyzed using the Index of Diamond Theory variables, and then SWOT analysis was used to formulate strategies to increase the competitiveness of the tourism sector in Ternate City.

\section{The purposes of this Research}

This study aims to: 1) Analyze the position of tourism competitiveness of Ternate City to other regions in North Maluku Province; 2) Formulate strategies to improve the competitiveness of the tourism sector in Ternate City. 


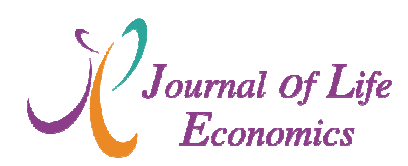

\section{LITERATURE REVIEW}

\section{Definition of competitiveness}

In various literature the use of competitiveness concept is found in many perspectives (Saptana, 2010: Balkyte \& Manuela, 2010). Competitiveness can be interpreted from the perspective of economic, political and business strategy of the company or industry. For the company, competitiveness is the ability to produce the right goods and services with the right quality, at the right price, and at the right time. This means meeting customer's needs is more efficiently and more effectively than others do (Edmonds, 2000: 20). This is in line with the opinion of Black et al. (2009) that competitiveness is a competitive ability of goods or services in the market based on the combination of price and quality with the same quality and established reputation (Snieška and Bruneckiene, 2009). The Organization for Economic Co-operation and Development (OECD) argues that competitiveness is understood as: "The ability of firms, industries, regions, countries or regions to produce relatively high factors and sustainable levels of work" (Hatzichronoglou 1996: 20). From these definitions, generally, competitiveness can be interpreted as the condition of an organization to compete with other organizations as its rival (Law, 2009).

\section{Competitiveness theory}

In various literatures, it is explained that competitiveness theory evolved from trade theory, derived from Adam Smith's absolute advantage theory (1776). However, before the rise of the absolute advantage theory, the world view was much influenced by the doctrine of mercantilism. One of the great figures born in mercantilism era was Thomas Mun. In his book, England's Treasure by Foreign Trade, he succeeded in contributing to the theory of international trade (Askinatin, et al., 2003: 20). Mercantilism viewed that the welfare of a country was only determined by the amount of assets or capital held by the concerned country such as the hoarding of money, precious metals / gold or silver (Schumacher 2012: 13 and Langdana and Murphy, 2014: 7-8). Therefore, global trade is very important for mercantilism. The way to get profit from free trade is to increase exports and suppress imports and the state policies should protect this (Askinatin, et al, 2003: 20 and Langdana and Murphy, 2014).

The mercantilism economic system began to disappear at the end of the eighteenth century, along with the emergence of a new economic theory proposed by Adam Smith in his book An Inquiry into the Nature and Causes of the Wealth of Nations (WN), published in 1776. In this book, Smith strikes the mercantilist who applies a zero sum game i.e. a country's advantage means loss to another country (Schumacher 2012: 13 and Langdana and Murphy, 2014: 8). Smith proposed a theory known as the "absolute advantage" that focused on the Labor of Value which meant that the more the number of labors used, the higher the value of the goods (Labor Theory of value). This theory emphasizes that the efficiency in the use of inputs, such as labor in the production process greatly determines the level of competitiveness. The advantage of the absolute-advantage theory is the occurrence of international trade between two countries if each country has a distinct absolute advantage between the two commodities. These differences result in mutually beneficial export and import interactions between the two countries. On the other hand, the weak point of this theory is that if there is only one country that has an absolute advantage (between two types of goods), then international trade will not occur because it is not mutually beneficial.

David Ricardo viewed the phenomenon of world trade was no longer in line with absolute advantage theory, which then he modified it by bringing up a theory of competitiveness called comparative advantage. His book, Principles of Political Economy and 
Taxation (1817), described that the cost comparative advantage or a state obtained a comparative advantage if it was more efficient in producing one good than that of other countries (Helpman 2014; Langdana and Murphy 2014: 11-14). The definition of excellence was in the form of comparison, not in the form of real added value (Tarigan (2005:79). Therefore, international trade will benefit a country if it makes product specialization, exports the goods in which if the country produces it thmeselves, it will relatively more efficient as well as imports goods in which if a country produces them, it will be less efficient (Faccarello 2015 and Schumacher, 2012: 25). This theory suggests that the main trigger of international trade is not an absolute advantage or absolute weakness, but a comparative advantage. The weakness of this comparative advantage theory is that it only explains the difference in the superiority among countries and its implications in international trade and division of labor, but it does not explain why there are differences in the superiority among these countries.

Michael E. Porter is a professor and strategy management expert. He tries to assess competitiveness from a micro (company) perspective to a macro (nation) perspective. His book entitled "The Competitiveness Advantage of Nation" published in 1990, describes the theory of competitive advantage with four major factors determining competitiveness (Porter, 1990: 71-129), i.e. factor conditions, demand conditions, related and supporting industries, firm strategy, structure and rivalry. In addition to these four factors, there are two factors that influence the interaction among the four factors, namely the role of government and the role of opportunity. Taken together, these factors form a system in enhancing the superiority of competitiveness called the diamond model, as shown in the following figure 1.

\section{FIGURE 1. PORTER'S DIAMOND FRAMEWORK}

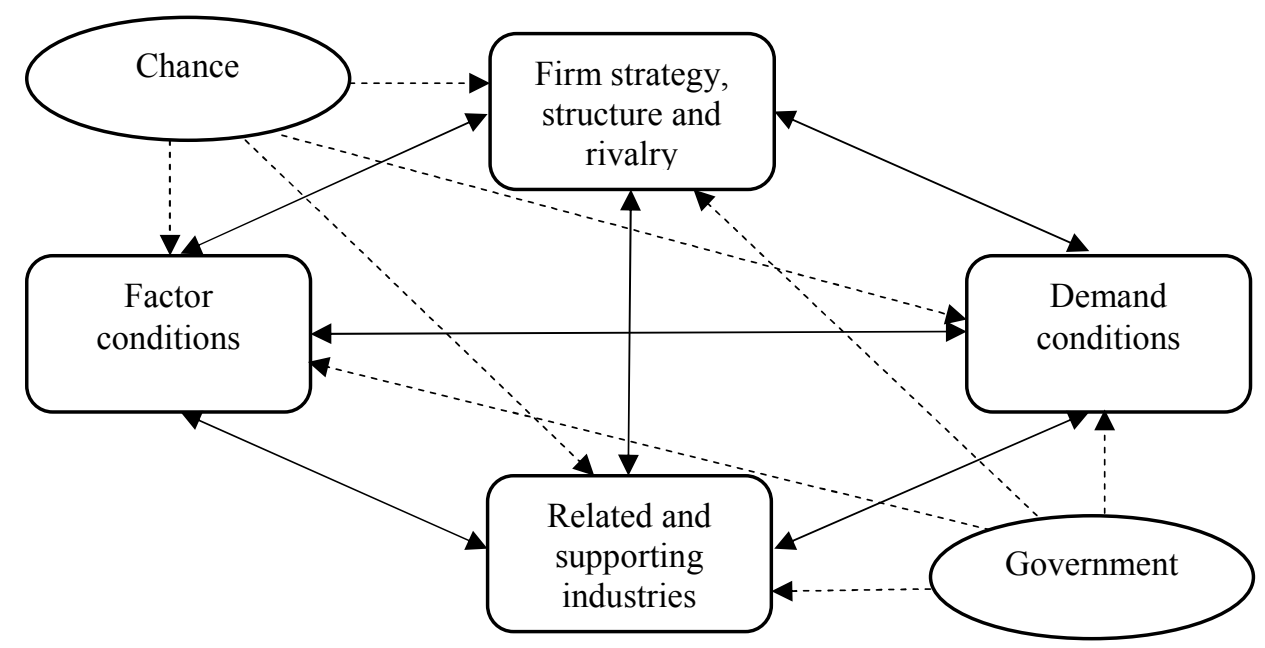

Source: Porter 1990:127

Factor conditions are variables that already exist and are owned by an industry. Porter divides this factor into two conditions, namely basic and advanced factors. The basic factors, such as natural resources, climate, location, unskilled and moderate labor, etc., are essentially inherited or created through simple and unsophisticated investments. Advanced factors, such as digital data of infrastructure communications, university research institutes, etc., are much more difficult to create, demanding large and continuous investments and often present the right institutional structures. Porter (1990: 74) asserted that the availability of factor conditions and the rate of its increase also contributed to the quality and competitiveness of an industry. 


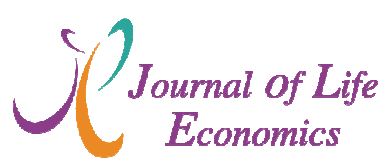

Demand conditions is related to sophisticated and demanding local customers. Demand conditions are the nature of origin for goods and services. The more advanced the society and the more demanding the customers in the country, the more the industry strives to improve the product quality or innovates to meet the needs of local customers. As with the globalization, the demand condition is not only coming from local but also from abroad

Related and Supporting Industries which have excellent competitiveness will provide potential advantages for industries in a region. This is due to the fact that the supplier industry produces widely used inputs which is important for innovation and internationalization. Synergy and efficiency can be created such as transaction cost, sharing technology, certain information or expertise that can be utilized by industry or other company. Another benefit of related and suppporting industries is the creation of well-improved competitiveness and productivity.

Firm Strategy, Structure and Rivalry including management practices, modes of organization, willingness to compete globally, company goals, etc., should be appropriate for an industry where the industry competes. The way to organize and manage a company is strongly influenced by the national conditions, such as the education system and historical development. This condition will motivate the company or industry to improve the quality of the products and to always look for new innovations. In this case, Porter (1990: 109) suggests looking at this determinant from the perspective of how companies are established and managed, and what is the nature of domestic competition because different countries have different cultures.

The Role of Government is a factor that does not directly affect the improvement of the competitiveness, but it affects the four determinants of competitiveness. Government role can occur through government policies such as regulation, education, tax and monetary policy. In addition, the government plays a role in facilitating the access to bureaucracy as well as improving the quality of infrastructure. The role of this government could be a position in favor of four condition factors in the diamond model frame, but also can have a negative effect.

The Role of opportunity is beyond the control of a company or government that will create a competitive environment and affect the level of competitiveness, such as new discoveries, basic technological breakthrough, external political development, and major changes in foreign market demand. The role of this opportunity will create or add additional wealth.

\section{Competition Strategies}

Porter (1998: 3) defines strategy as the creation of a unique and valuable position, involving a different set of activities. Meanwhile, Heizer and Barry (2006: 32) mention strategy as an organizational action plan to achieve the mission. Each functional area has a strategy to achieve its mission and to help the organization achieve its overall mission. Although the emphasis of these two definitions differs, where Porter emphasizes unique and valuable positions, and Haizer and Barry emphasize the mission's accomplishment plan, but both illustrate that strategy is the creation of favorable positions in order to achieve certain goals. It is commonly found that the strategy is the creation of the right position to excel in competition (Porter 1998: 3, Heizer and Barry, 2006: 32; David and David, 2015: 43; Sedermayanti, 2015: 2). Thus, competition strategy is defined as position creation through internal and external analysis that enables the industry or company to excel in competition. 


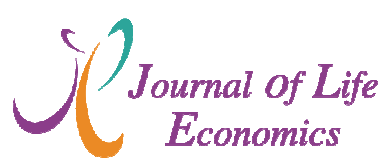

\section{Tourism}

Tourism is a temporary travelling, from one place to another place with the intention not to do business or to make a living in the visited place but merely to enjoy the journey, sightseeing, recreation or fulfilling various desires (Yoeti , 1996: 109), and can be done repeatedly (Muljadi and Warman, 2016: 8; Suryadana and Octavia, 2015: 30). From the definition, tourism refers to four basic things, namely travelling, from one place to another place, a relatively short time and recreational purposes. In line with this, Word Tourism Organization (2012) defines tourism as follows: The activities of persons traveling to and staying in places outside their usual environment for not more than one consecutive year for leisure, business and other.

Based on its types, Tourism can be divided into two categories (Suryadana and Octavia, 2015: 32), namely: 1) Natural Tourism which consists of: Coastal tourism (marine tourism), Ethnic tourism; ecotourism; Buru Tour, Agro Tour, 2) Socio-Cultural Tourism, which consists of: Historical heritage; Museums and other cultural facilities. The basic components of tourism that interact with one another (Inskeep, 1991: 38; Zaei and Zaei, 2013: 14) are: a) Attractions and tourist activities. The concerned tourism activities include all matters related to the natural environment, culture, the uniqueness of an area that attract tourists to visit a tourist object, such as: Theme Parks, Natural Areas, Cultural, Educational, Events (all types), Indigenous; b) Accommodation is a variety of hotels and various other facilities related to services for tourists, such as: Motels, Serviced Apartments, Camping Grounds, Farm Stays, Guest Houses, Bed \& Breakfast, Backpackers, Caravan Parks, Cabins, Houseboats, Resorts; c) Tourist facilities and services are all facilities needed in planning tourist areas, including tour and travel operations (also called welcoming services). The intended facilities are restaurants and various other places to eat, shops to sell handicrafts, souvenirs, specialty shops, grocery stores, banks, money changers and other financial service facilities, tourist information offices, beauty salon, health care facilities, public security facilities (including police office and fire stations), and travel facilities for in and out (such as immigration and customs offices); d) Transportation facilities and services; e) Other infrastructure, such as the provision of clean water, electricity, drainage, sewerage, telecommunications (such as telephone, telegram, telex, facsimile, and radio); f) Institutional elements are the institutions needed to build and manage tourism activities.

\section{The Measurement of Tourism Competitiveness}

The measurement of tourism competitiveness is fairly interesting because it is a crucial factor for the success of the tourism industry (Mihalic, 2000; Crouch and Richie, 1994, 1995, 1999; Dwyer et al, 2000). According to Berdo (2016) there is no universal model to provide an appropriate evaluation / measurement towards the tourism competitiveness, but the use of models and techniques depends on the researcher's ability and the availability of the data. The analysis of tourism competitiveness in this study used Diamond Theory (Porter, 1990: 71-129), which consists of four main variables. Chin, at al (2015) mentioned that four variables from the Porter's model were proved successfully and promoted the competitiveness in Bali tourism. There are some researchers who use the Porter diamond frame, including Huttasin, at al (2015) in which his research entitled "Towards Tourism Development Of The Isan Region, Northeastern Thailand", revealed that the low competitiveness of tourism sector in Ubon Ratchathani was due to cultural constraints, the lower quality of factor conditions especially the lack of skilled tourism workers, less coordination in the chain of tourism value, less cooperation between the public and private sectors and sophistication of demand 
conditions. Croitoru's research (2011) on "Tourism Competitiveness Index-An Empirical Analysis Romania vs. Bulgaria ", showed the competitiveness index of Romania is lower than that of Bulgaria. Of the 3 main variables, Bulgaria outperforms Romania. Meanwhile, from 14 indicators (derived from primary variables), Bulgaria outperformed 12 indicators, while Romania only excelled in 2 indicators of environmental sustainability, in the form of protection of rare species and environmental protection. The most favorable thing of the Bulgarian competitiveness index is the political, administrative and legal system that provide a level of security for tourists, investors and business actors. This research has similarities with previous studies, such as the use of diamond theory and its analytical methods, but the difference lies in the use of SWOT analysis that is integrated in formulating strategies to improve the competitiveness of the tourism sector of Ternate City.

\section{RESEARCH METHOD}

\section{Research approach}

This research included qualitative design, which aims to find out the meaning of natural events (Emzir 2011: 15, Mukhtar 2013: 10, and Sugiyono (2016: 8), about the position of tourism sector competitiveness and the determinants of competitiveness with the intention of, it can be formulated an improvement strategy of tourism sector competitiveness inTernate City.

\section{Location and Time of Research}

The research was carried out in Ternate tourism sector, but its analysis included other areas in North Maluku Province for its comparison including West Halmahera, Central Halmahera, Sula Islands, North Halmahera, South Halmahera, East Halmahera, Morotai and Tidore Islands. This research was started from March to August 2017.

\section{Method of Collecting Data}

The data were collected through documentation technique, i.e. collecting secondary data as main data such as PDRB, APBD, infrastructure condition, tourism object, workforce, accommodation provider industry, and number of tourist visit. These data were obtained from the Tourism Office, the Central Bureau of Statistics, the Regional Revenue and Asset Management Department, the Regional Development Planning Board, and the Finance Ministry of the Republic of Indonesia. Interview techniques were also conducted to obtain information supporting the secondary data. the informants involved were a number of leader elements of the of government agencies in Ternate City, including the Office of Manpower, Tourism Office, Regional Income and Asset Management Department, Environmental Agency, Regional Development Planning Agency.

\section{Data Aanalysis}

The Data were analyzed using mixed methods (Kiessling and Harve, 2005: 22; Swanson and Holton 2005 in Sugiarto, et al, 2015: 46). The analysis used shift share analysis through time series data PDRB 2011-2015, while indexation technique used data in 2015 and SWOT used the data from shift share and indexation result. Shift share technique aims to determine the tourism performance and benefits of the last five years. Indexation technique aims to determine the competitiveness index of tourism sector. Then the result of shift share analysis and indexation becomes part of SWOT analysis input to formulate strategy to 
increase the competitiveness of tourism sector. The Shift Share analysis used follows the Pratiwi at al (2016) model, where the regional Growth Component consists of three variables decomposition become component of deviation $\Delta \mathrm{Yi}$, is regional growth component (RG), proportional or industrial mix growth component $(\mathrm{PG})$, and regional share growth component (RSG). The equation becomes:

$$
\begin{aligned}
& \Delta \mathrm{Yi} \quad=\mathrm{PRij}+\mathrm{PPij}+\mathrm{PPWij} \\
& \text { or detail can be declared } \\
& \Delta Y i \quad=Y^{\prime} i j-Y i j \\
& \text { PRij }=(\mathrm{Ra}) \mathrm{Y}_{\mathrm{ij}} \\
& \mathrm{PPij}=(\mathrm{Ri}-\mathrm{Ra}) \mathrm{Y}_{\mathrm{ij}} \\
& \text { PPWij }=(r i-R i) Y_{i j} \\
& \mathrm{Ri}=\frac{\mathrm{Y}^{\prime} \mathrm{i}-\mathrm{Yi}}{\mathrm{Yi}} \quad ; \quad \mathrm{Ra}=\frac{\mathrm{Y}^{\prime}-\mathrm{Y}}{\mathrm{Y}} \quad ; \quad \mathrm{ri}=\frac{\mathrm{Y}^{\prime} \mathrm{ij}-\mathrm{Yij}_{\mathrm{ij}}}{\mathrm{Yij}^{\prime}}
\end{aligned}
$$

Regional Growth $(\mathrm{RG})$ which has positive value means that the region is growing faster than the average growth province. Meanwhile, the negative sign gives an indication that a regional growth is slower than the average province growth. Proportional Growth (PG) which has positive value gives an indication that sector-i (regional) is rapid sector, the sector is growing faster than the economy growth in totality and negative values indicate that the sector is slow. Regional share growth (RSG) indicates competitiveness which has a sector-i in a region compared to the same sector in the region of comparison (the region one or two level above, or used a national scope).

\section{Indexation Analysis}

This analysis is used to determine the level of competitiveness between one region to other regions in one province. This study will compare the competitiveness of Ternate tourism city to the other Nine Regencies / Cities in North Maluku Province. Calculates the tourism index of the constituent indicators (variables) in Diamond Model framework, which consists of four main factors, namely: 1) factor condition consisting of the number of tourist objects and the workers; 2) demand conditions consisting of the number of domestic and foreign tourists; 3) regional strategy consisting of good road conditions and government budgets for tourism; and 4) supporting and related industries comprising of hotels, inns, restaurants, and cafes. Calculating the index required standardization of data on each indicator. The standardized data in this study adapted the formulation used by Fernando (2014), with a slight adjustment of the symbols in the above shift share, as follows.

$$
X_{i j}^{\prime}=\frac{\text { Xij-Minj }}{\text { Marij-Minj }}
$$


Where:

$\mathrm{X}_{\mathrm{ij}}=$ The standardized $\mathrm{i}$-th district value for the $\mathrm{j}$-th variable;

$\mathrm{Xij}=$ the data value of $\mathrm{i}$-th regency/city $\mathrm{j}$-th variable ;

$\operatorname{Min}_{\mathrm{j}}=$ minimum value of $\mathrm{j}$-th variabel ;

$\operatorname{Max}_{j}=$ maksimun value of $j$-th variabel.

\section{SWOT Analysis}

The SWOT analysis is used as a continuation of the previous analysis, where the results of shift share and indexation become the input for performing the SWOT analysis. The stages in performing the SWOT analysis adopted several explanations from the experts such as David and David (2015), Sedermayanti (2014), Yoeti (1996), Rangkuti (2014) and Muhammad (2008 and 2013). SWOT analysis is mapped into two parts, namely Internal Factor Analisys (IFA) which consists of elements of strength and weakness and External Factor Analisys (EFA) which consists of elements of opportunity and challenge. Each element consists of strategic factors for measuring, rating and scoring professionally to weigh the condition of each element. The IFA and EFA results are mapped using four main quadrants. Furthermore, to determine the strategic position of the tourism sector, this research used 8 quadrants developed by the Management Board of Economics Faculty from the University of Indonesia (Muhammad, 2008: 65 and 2013: 176). Finally, the formulation of strategy refers to IFA and EFA strategy positions consisting of four alternative strategies, namely: SO Strategy: utilizing all power to seize the maximum possible opportunity; ST Strategy: use force to overcome threats; WO strategy: minimize the weaknesses to capture opportunities; and, WT Strategy: minimize the weakness and avoid threats.

\section{RESULTS AND DISCUSSIONS}

\section{Research result}

\section{Object of research}

Ternate City is an archipelago consisting of eight islands, five of which are inhabited islands (Ternate, Hiri, Moti, Mayau, Tifure) while the other 3 uninhabited small islands are Maka, Mano and Gurida. Ternate City consists of seven sub-districts and seventy seven villages, in which 56 villages $(72,73 \%)$ are located in coastal areas and the other 21 urban villages $(27,27 \%)$ are not coastal areas (BPS Ternate, 2016). Ternate City is the main gate of North Maluku province entrance because it has sea port and airport. Up to now, Ternate still keeps historical and cultural stories that become evidence of its glory in the past. These glory evidence from the past is now becoming a historical and cultural attractions arousing amazement reactions, such as Kedaton Sultan Ternate in which it keeps objects of high historical value and Sultan Ternate Mosque using a combination of ancient Chinese and Javanese architecture, Tolukko Fortress, Kastela Fortress, Kalamata Fortress, Oranje Fort, Traditional Ceremony of Kololi Kie and Legu Gam Festival (people's party). Besides keeping historical and cultural treasures, Ternate City also has natural potential and interesting geological phenomenon such as Tolire Lake, Gamalama Mountain, Sulamadaha Beach, Bobane ici Beach, Angus Rock, and Nukila Park (Ternate City Tourism Office 2016).

\section{Competitiveness of Ternate tourism sector}

Ternate tourism sector contributes to the regional economy income. This can be seen from the Regional Growth/PR of the tourism sector in the period of 2011-2015 whose value is 
positive with an average growth of $6 \%$. The positive value of PR means the growth of tourism sector in Ternate City is greater than the growth of North Maluku Province. The highest growth occurred in 2011-2012 reaching up to Rp. 4,631,5325 million (7\%).

TABLE 1. SHIFT SHARE ANALISYS TOURISM SECTOR IN TERNATE

\begin{tabular}{|l|c|c|c|c|}
\hline \multicolumn{1}{|c|}{ Component (Million) } & \multicolumn{4}{c|}{ GROWTH YEARS PERIOD } \\
\hline & $2011-2012$ & $2012-2013$ & $2013-2014$ & $2014-2015$ \\
\hline Regional Growth/PR & 4631.5325 & 4178.184 & 3681.6425 & 4777.6578 \\
\hline PR \% & 7 & 6 & 5 & 6 \\
\hline Propositional Growth/PP & -1323.295 & -696.364 & 2945.314 & -796.2763 \\
\hline PP \% & -2 & -1 & 4 & -1 \\
\hline Regional Share Growth/PPW & 0 & 696.364 & -736.3285 & 0 \\
\hline PPW \% & 0 & 1 & -1 & 0 \\
\hline
\end{tabular}

Source: Author 2017

Proportional growth of tourism sector in the period of 2011-2012 reached the value of Rp. $-1,323,295$ million $(-2 \%)$. The value of $\mathrm{PP}<0$ indicates that the tourism performance is experiencing slow growth. Furthermore, in 2012-2013 the growth is still slow with a value of Rp. -696,364 million (-1\%). Positive growth occured in 2013-2014 reached up to 2.945.314 million (4\%), but in 2014-2015 the slow growth happened again with a value of Rp. 796.2763 million (-1\%). Regional Share Growth in 2011-2012 shows that the tourism sector is relatively powerless (PPW value $=$ Rp.0), but in 2012-2013 the tourism sector is able to compete better than other regions in North Maluku province as it receives a positive value of Rp. 696,364 million (1\%). Meanwhile, in 2013-2014 PPW tourism sector deteriorated again with the value of Rp. -736.3285 million (-1\%) and in 2014-2015 it could improve again, although its position is relatively not competitive.

The occurrence of fluctuations in the performance of the tourism sector is strongly influenced by the competitiveness condition of the tourism sector itself and its determinant factors. Competitiveness Position of tourism sector of Ternate City in 2015 and its determinant factors are explained through the Diamond Model framework, which consists of four main factors, namely: 1) factor condition consisting of the number of tourist objects and the workers; 2) demand conditions consisting of the number of domestic and foreign tourists; 3 ) regional strategy consisting of good road conditions and government budgets for tourism; and 4) supporting and related industries comprising of hotels, inns, restaurants, and cafes. Of the four competitiveness factors, the tourism competitiveness of Ternate City is at the top position among the eight regencies / cities in the province of North Maluku, as shown in the following figure. 


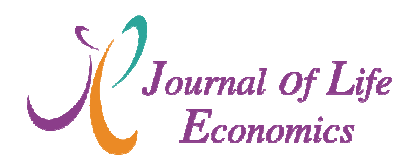

FIGURE 2. TOURISM COMPETITIVENESS INDEX

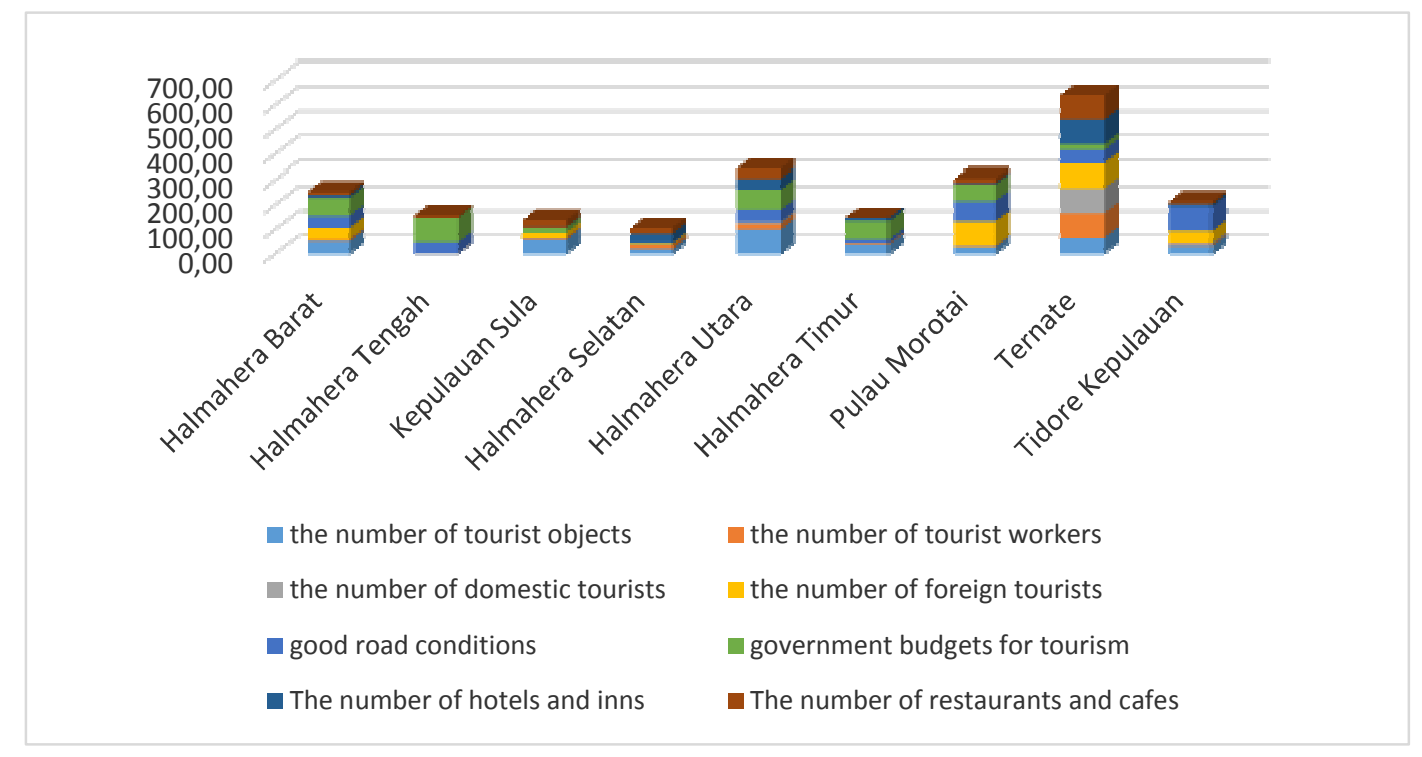

Source: Author 2017

The competitiveness of Ternate tourism sector is strengthened by the supporting and related industries (hotels, lodges, restaurants and cafes), the number of manpower and tourist visits. The number of hotels and inns in Ternate City from 2011 is 666 units, then it reached up to 685 units by 2015. The number of restaurants and cafes in 2011 is 52 units, then becoming 90 units in 2015. From these 5 years span, supporting and related industries have increased very well. The increase has an impact on the absorption of labor, where in 2015 the labors absorbed in the tourism sector are 791 people. External factor that supports the competitiveness of Ternate tourism sector is a strategic geographical location, i.e. as a center of transportation and trade routes in North Maluku Province (BPS, 2016). This is in line with Porter's (1990: 72) opinion that location is the basis of the factor conditions. Strategic location is part of static excellence (Saptana, 2010). Thus, this strategic location is beneficial to Ternate tourism because it affects the cost of travel. Tourists from outside North Maluku Province will spend relatively smaller travel costs if they travel in Ternate City, rather than traveling in other areas. Utami and Hartono (2016) view that the value of price elasticity affects the demand of tourists. The demand from tourists to certain destination will decrease when there is an increase in the destination cost in which the percentage decrease in demand is higher than the percentage increase in prices. Another factor that supports the competitiveness of Ternate tourism is the development of information and communication technology that facilitates the sharing of information and openness to the outside world, thus providing greater opportunities for the development of the tourism sector. This is in line with Andriotis' (2004) research towards the traveling and tourism industry in Yunai showing that technology is very influential in supporting the competitiveness.

Beside highlighting factors that have high competitiveness index, this study also looks at low-index factors that affect tourism competitiveness. The government role in developing tourism object and determining budget allocation policy is still considered low so that the role of Ternate government is under North Halmahera. The allocation of tourism budget in 2011 is only $0.37 \%$ or Rp. $1,972,000,000$ of the total budget in Ternate City as many as Rp. 532.219.000.000, -. Then the budget allocation in 2012 increases up to $0.50 \%$. In 2013 there is no budget allocation for tourism. Then in 2014 the allocation is given as many as $0.40 \%$ and $0.17 \%$ in 2015 . The low role of the concerned government can also be seen in the 


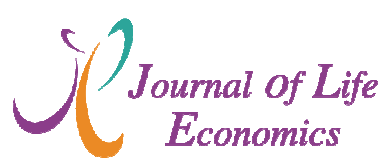

documents of the Medium Term Development Plan (RPJMD) of Ternate City during 20112015 , in which of 11 prioritized programs, there is no tourism priority.

The government role in developing the tourism sector affects the quality and the quantity of tourism sector in Ternate City. The Research of Wu and Chang (2013), Othman and Rosli (2011), Wu, et al (2013) and Damanik (2013: 50) found a similar fact, where political will and the consistency of government policies affect tourism competitiveness. Government is required to develop physical infrastructure, public facilities and infrastructure that play an important role in productivity, although there still remains a debate concerning the size of its influence (Calderon and Serven, 2004; Garcia-Milà et al., 1996; Gramlich, 1994; Aschauer, 1989). The role of the government can also provide efficient access to capital which is important for the companies to make the long-term investments necessary to raise the level of productivity (Ang, 2008; Aghion et al. 2007; Levine, 2005; King and Levine, 1993; Rajan and Zingales, 1998).

\section{Strategy for Increasing the Competitiveness of Tourism Sector in Ternate City}

The competitiveness indexation of the tourism sector shows some weaknesses possessed by the tourism sector of Ternate City such as the role of the government, the tourism object and the budget policy. This weakness causes the percentage of tourism growth in Ternate City tends to decrease. This fact gives a negative signal that the position of tourism competitiveness in Ternate City could deteriorate due to internal weakness, competitive pressure and social situation change (David and David (2015: 43). Based on SWOT analysis, the internal condition (strength and weakness) owned and external situation (opportunities and challenges) faced by Ternate tourism sector are revealed.

The internal condition that becomes the strength and is owned by Ternate tourism consists of the following strategic factors: the availability of relatively affordable tourism object; the sufficient availability of tourism labor; adequate accommodation for hotels and inns; adequate restaurants and cafe; the good security level of travel; the availablity of adequate infrastructure of information and communication technology; the existence of historical and cultural wealth that is well known and reputable in Indonesia as well as in the World. Meanwhile the weaknesses are: The role of government is low; The absence of specific institution for tourist management; The database and tourist information center are not available; The lack of common perceptions among the government, entrepreneurs and society concerning tourism management; the development of tourist object is static and less innovative; Low environmental protection especially the abrasion in coastal tourist areas; The low number of tourist objects and attractions.

The external situation that becomes profitable opportunity for Ternate tourism consists of the following strategic factors: Ternate City is a center of trade and education; Ternate has both air and sea transportation; it has increasingly improved people's economic level that can encourage tourist motivation; The ability of people to access information is increasing; National development policy, the acceleration of transportation infrastructure and the connectivity of information and communication technology network (ICT) (RPJMN 20152019) are well-improved; The interest of domestic tourists is quite high; The interest of foreign tourists is quite high. Meanwhile the things that become the threat and potentially disadvantageous are: Gamalama mountain eruptions are frequent and can reduce the motivation of tourists; National and regional security conditions; The demand of sustainable tourism paradigm affects tourist behavior, especially foreign tourists; Demands for the 
diversity of destinations. Furthermore, S-W score tabulation was performed to obtain IFA values, while the EFA score was obtained from the O-T score tabulation.

\section{TABLE 2. SWOT MATRIX}

\begin{tabular}{|c|c|c|c|c|}
\hline \multirow{13}{*}{ 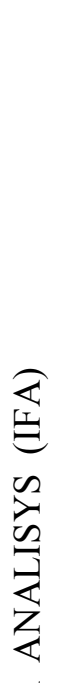 } & STRENGTH (S) & Weight & Rating & Score \\
\hline & 1. Availability of affordable tourism object. & 0,2 & 4 & 0,8 \\
\hline & 2. The adequate numbers of tourism workforce. & 0,1 & 4 & 0,4 \\
\hline & 3. hotel and inn accommodation & 0,2 & 4 & 0,8 \\
\hline & 4. the availability of adequate restaurant and cafe & 0,1 & 4 & 0,4 \\
\hline & 5. the satisfying security of tour & 0,1 & 4 & 0,4 \\
\hline & $\begin{array}{l}\text { 6. the availability of adequate infrastructure of information } \\
\text { and coomunication technology }\end{array}$ & 0,1 & 4 & 0,4 \\
\hline & $\begin{array}{l}\text { 7. the existence of well-known historical and cultural wealth } \\
\text { in Indonesia }\end{array}$ & 0,2 & 4 & 0,8 \\
\hline & Total sum & 1,0 & & 4,0 \\
\hline & WEAKNESS (W) & Weight & Rating & Score \\
\hline & 1. Government role is low & 0,2 & 1 & 0,2 \\
\hline & 2. There is no specific institution for managing the tourism & 0,2 & 2 & 0,4 \\
\hline & 3. There is no database and information center for tourism & 0,1 & 2 & 0,2 \\
\hline \multirow{6}{*}{ 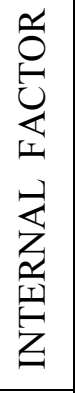 } & $\begin{array}{l}\text { 4. There is no common perception among government, } \\
\text { enterpreneur and society concerning tourism management }\end{array}$ & 0,1 & 2 & 0,2 \\
\hline & 5. Tourism object development is static and less innovative & 0,2 & 2 & 0,4 \\
\hline & $\begin{array}{l}\text { 6. There is a lack of environmental protection especially the } \\
\text { abration in the coastal areas of tourism. }\end{array}$ & 0,1 & 2 & 0,2 \\
\hline & 7. Poor numbers of tourism object and attraction & 0,1 & 2 & 0,2 \\
\hline & Total sum & 1,0 & & 1,8 \\
\hline & \multicolumn{4}{|c|}{ IFA score $: \mathrm{S}-\mathrm{W}=4,0-1,8=2,2$} \\
\hline \multirow{9}{*}{ 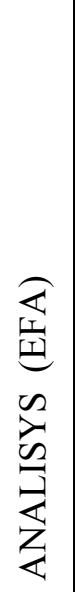 } & OPPORTUNITY (O) & Weight & Rating & Score \\
\hline & 1. Ternate City is the center of trade and education & 0,2 & 4 & 0,8 \\
\hline & 2. It has both air and sea transportation & 0,2 & 4 & 0,8 \\
\hline & $\begin{array}{l}\text { 3. it has increasingly improved people's economic level that } \\
\text { can encourage tourist motivation }\end{array}$ & 0,1 & 3 & 0,3 \\
\hline & 4. The ability of people to access information is increasing & 0,1 & 3 & 0,3 \\
\hline & $\begin{array}{l}\text { 5. National development policy, the acceleration of } \\
\text { transportation infrastructure and the connectivity of } \\
\text { information and communication technology network (ICT) } \\
\text { (RPJMN 2015-2017) }\end{array}$ & 0,1 & 4 & 0,4 \\
\hline & 6. The interest of domestic tourists is quite high & 0,1 & 2 & 0,2 \\
\hline & 7. The interest of foreign tourists is quite high & 0,2 & 4 & 0,8 \\
\hline & \begin{tabular}{|l|} 
Total sum \\
\end{tabular} & 1,0 & & 3,6 \\
\hline \multirow{7}{*}{ 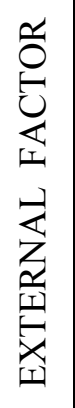 } & \begin{tabular}{|l|} 
THREAT $(\mathrm{T})$ \\
\end{tabular} & Weight & Rating & Scor \\
\hline & $\begin{array}{l}\text { 1. Gamalama mountain eruptions are frequent and can reduce } \\
\text { the motivation of tourists }\end{array}$ & 0,2 & 1 & 0,2 \\
\hline & 2. National and regional security conditions & 0,3 & 1 & 0,3 \\
\hline & $\begin{array}{l}\text { 3. The demand of sustainable tourism paradigm affects tourist } \\
\text { behavior, especially foreign tourists }\end{array}$ & 0,3 & 2 & 0,6 \\
\hline & 4. Demands for the diversity of destinations & 0,2 & 2 & 0,4 \\
\hline & Total sum & 1,0 & & 1,5 \\
\hline & & core & 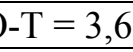 & $5=2,1$ \\
\hline
\end{tabular}

Source: Author 2017 
To find out the quadrant location of the priority strategy for increasing the competitiveness of the tourism sector in Ternate City, the formulation of OT line as EFA with value 2.1 and SW line as IFA with value 2.2 is used as shown in the following figure.

FIGURE 3. QUADRANT OF TOURISM SECTOR POSITION

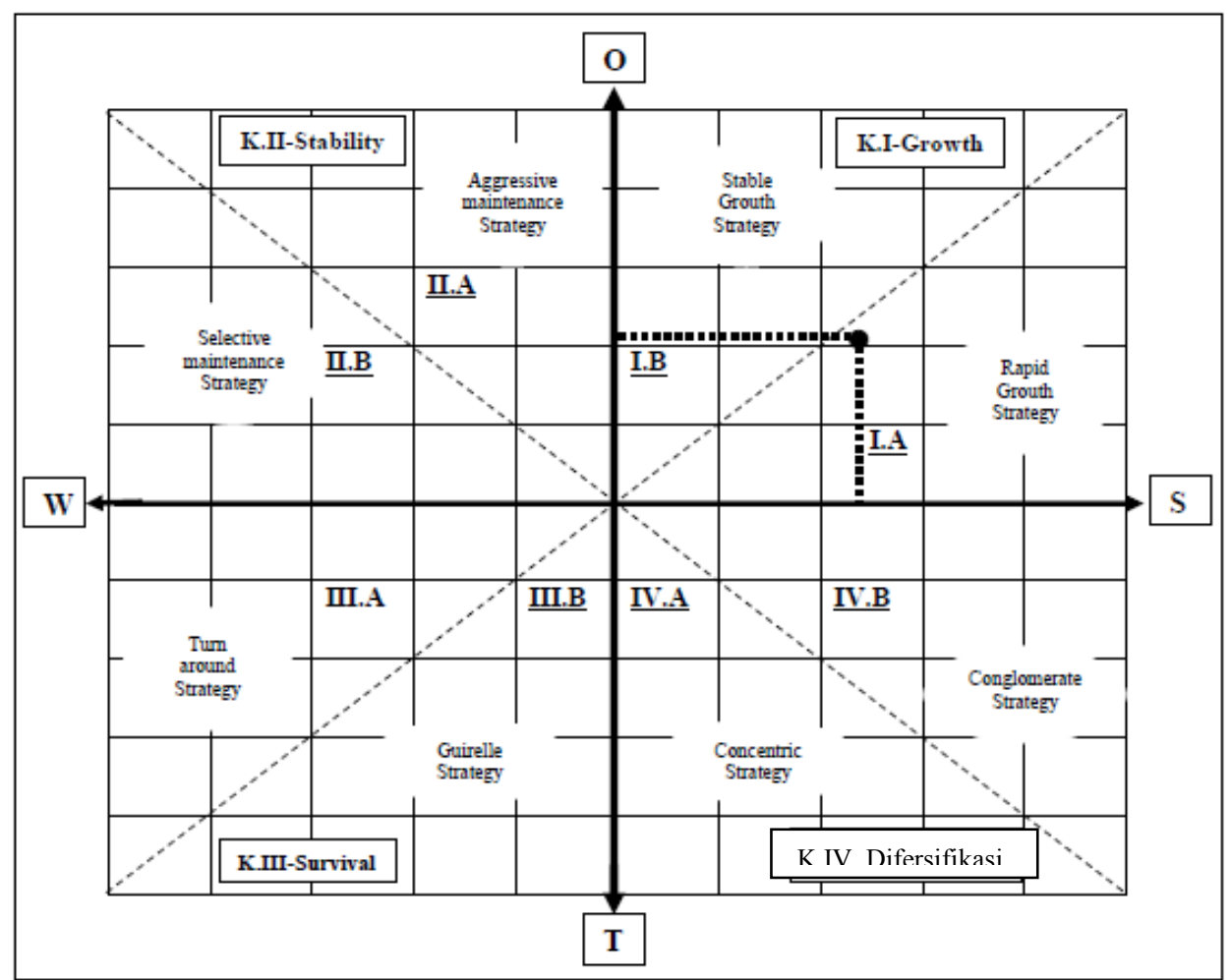

Source: Author 2017 (LM-FEUI Model, in Muhammad 2008:65)

The strategy that must be implemented to improve the competitiveness of Ternate tourism sector lies in the I.A quadrant, which is between internal strength (strength) and external opportunities (opportunity), where strength is weighted bigger than opportunity so that the alternative strategy is in the "Rapid growth strategy". This strategy is done to increase the growth rate of tourist visits more quickly and to increase businessman income through the increasing quality of strength factor to maximize the utilization of opportunity. Thus, the strategy used is the S-O (Strength-Opportunity) Strategy, i.e. a strategy that uses the strength to capture the opportunities, which are as follows:

1) Utilization of information and communication technology (ICT) to attract foreign and domestic tourists. This strategy consists of two categories; First, the utilization of ICT for tourism management such as the manufacture of digital-based data base and geographic information systems (GIS). The use of GIS application for tourism planning can provide strategic opportunities and increase tourism competitiveness (Jovanović and Angelina, 2008 and Marzuki et al 2011). Second, the ICT is used as a campaign media such as the creation of tourism websites and ICT-based applications to produce effective promotion activities and tourism marketing (Prasetya, 2011 and Soteriades, et al, 2004). ICT also facilitates individuals to access the information of tourism product from anywhere at any time. Tourism companies can reach the targeted customers around the world (Bethapudi, 2013), thus ensuring the sustainability of tourism (Wöber, 2003). 


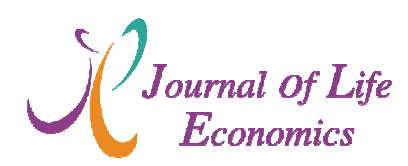

2) Establish cooperative system with the surrounding area in an integrated tourism management. This strategy emphasizes two things. The first is tourism promotion cooperation and the second is sales tour package cooperation. These two forms of cooperation promote participation and mutual relationships (Kadi, et all, 2015). This strategy is proved to be implemented successfully in many regions, although it used different terms. Jolliffe and Tom (2004) see the term partnership as a tourism approach in the Scottish highlands with three components of building partnerships, namely local and regional tourism, economic development agencies and art instititution. This approach gives benefits such as: 1) establishing relationships among various institutions and organizations; 2) strengthening the culture and supporting the art accessibility; 3) adding the main product and enhancing the attraction of the tourist destination; 4) creating economic impact. Meanwhile Saftic, et al (2011) see the term as a stakeholder approach i.e. a management approach that increases tourism visitors and supports the development of sustainable tourism.

3) Establishing cooperation between local government and central government in developing the tourism sector. The Cooperation with the central government can help overcome obstacles such as technological infrastructure development, transport channel and tourism promotion. This cooperation can provide benefits for the region as well as for the country such as the increasing number of tourist visits and the improvement of regional and national tourism performance. Government can activate the crucial factors of tourism competitiveness, such as development policies, political consistency (Damanik, 2013: 50), national security, regulation that can protect the environment, social and culture and (Xin and Jennifer, 2014) long-term investment.

4) Empowering tour operators in attracting tourists. This strategy is carried out to increase their capacity to understand the regional tourism sector and international market conditions. Tour Operator is a party that operates a trip to a certain region or operates a series of tourist activities. Tour operators have communication network with various travel agencies, so they have an important role in promoting regional tourism to tourists (Tathagati and Indscript, 2015: 9). Tour operators become one element that play an important part in the tourism competition (Andriotis, 2004; Okech, 2004).

5) Developing the quality and the quantity of scientific and cultural tourism. These strategies further highlight Ternate as a sultanate and educational city, which has a scientific, artistic and cultural nuance.

6) Facilitating the tourists' entrance to the tourist area.

This strategy is related to the customer service that prioritizes the satisfaction of the tourists, because it can establish loyalty behavioral (loyalty), i.e a repeated visit and inviting others to visit a tourist destination (Valle, et al, 2006). This can support the sustainability aspect of a tourism (Gracan, et al, 2008); (Stipanovic, et al, 2008); (Jovicic and Vanja, 2008); (Meyer, 2012); and (Wu and Chang, 2013).

\section{CONCLUSIONS AND LIMITATIONS}

Ternate tourism sector contributes to the improvement of local economy and employment. Based on the analysis of shift share, it is known that the tourism sector in the period of 2011-2015 has a Regional Growth that is bigger than the Province growth, but the growth is fluctuative and tends to decrease. The period of 2012-2013 is the point where Ternate Tourism sector has competitiveness and specialization. This is due to the increasing development of tourism industry and the increasing number of tourist visits. Through Porter diamond framework, it is known that the total competitiveness of tourism sector in Ternate 


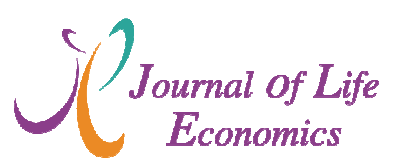

City in 2015 is in the top position of 9 regencies / cities. The main factor determining the competitiveness of tourism is supporting and related industry activities, such as hotels, lodging, restaurants, and cafes. In addition, the absorption of labor and the number of domestic and foreign tourists also increase the competitiveness of the tourism sector in Ternate City. Supportive external conditions are geographical location, in which Ternate City is well-known as transportation route and main gate of North Maluku Province and it has good development of information and communication technology infrastructure. However, there are some low index indicators such as tourism object which is still under North Halmahera, and the tourism budget allocation policy which is still under North Halmahera, Morotai Island, West Halmahera, Tidore Island and Central Halmahera. This shows that the government role in Ternate City in terms of tourism sector development is still poor and this can influence the competitiveness of its tourism. Basically, Ternate City can improve the competitiveness of its tourism sector in a sustainable manner through the following strategies: 1) The use of information and communication technology to attract foreign and domestic tourists; 2) Establishing cooperation system with the surrounding area in an integrated tourism management; 3) Establishing cooperation between the local government and the central government in developing tourism sector; 4) Empowering tour operators in attracting tourists; 5) Developing the quality and the quantity of scientific and cultural tourism; 6) Facilitating the tourists' entrance to the the tourist destination area.

There are some limitations in this study, including: Limitations of data, so that there are some indicators that are not included as input analysis. Another limitation lies in the Diamond Model framework, where the analysis is only performed towards the existing variables without analyzing the actors being responsible for causing these variables. As a recommendation for further research, it is better to analyze the competitiveness of tourism using the Dong Sung Cho (1998) model. Beside the competitiveness of tourism, research on factors that influence the behavior of tourists is also very important including research on the role of tour operators in tourism competition.

\section{CONTRIBUTIONS}

The competitiveness of the tourism sector can increase the number of visits, encourage the regional economic growth and expand the employment for the community. Therefore, it is necessary to integrate all components of society to unite the perception in developing the tourism sector of Ternate City. Thus, it is recommended to do the following things: 1) Establishing a tourism institution so that the tourism sector can be managed competitively; 2) Providing the data base for research and tourism development; 3) Designing a management model that applies sustainable tourism principles; 4) Increasing the competitiveness of the tourism through the improvement of the the quantity and the quality of tourist attractions, regulations and budget policies, establishing cooperation both at regional and at national levels; 5) Creating innovations that can attract tourists; 6) Establishing hospitality to the tourist visitors and actively participate in the tourism development. 


\section{REFERENCES}

AGHION, P., P. HOWITT, D. MAYER-FOULKES. (2007). The Effect of Financial Development on Convergence: Theory and Evidence, Quarterly Journal of Economics 120 (1), p 173-222.

ANDRIOTIS, K (2004). Revising Porter's Five Forces Model for Application in the Travel and Tourism Industry. The Journal of The College Of Tourism And Hotel Management. No.4 2004, p.7-20.

ANG, J. (2008). A Survey on Recent Developments in the Literature on Finance and Growth, Journal of Economic Surveys 22 (3), p 536-576.

ASCHAUER, D. A. (1989). Is Public Expenditure Productive? Journal of Monetary Economics 23 (2), p 117-200.

ARYUNDA, HANNY (2011). Dampak Ekonomi Pengembangan Kawasan Ekowisata Kepulauan Seribu. Jurnal Perencanaan Wilayah dan Kota, Vol. 22 No. 1, April 2011, h.1- 16.

ASKINATIN, M; YUDI. W DAN MUCHDIE (2003). Konsep Daya Saing Wilayah Perspektif Teknologi. (Penyunting Yudi Widayanto dan Binuko D. S). Badan Pengkajian dan Penerapan Teknologi pengkajian kebijakan teknologi (BPPT), Jakarta.

BALAN, D., BALAURE, V., \& VEGHES, C. (2009). Travel and tourism competitiveness of the world's top tourism destinations: An exploratory Assessment. Annales Universitatis Apulensis series Oeconomica, 11, (2).

HEIZER, JAY AND BARRY RENDER (2006). Operations Management. Pearson Education. Amerika.

BERDO, SONILA (2016). Application Cases of Main Tourist Destination Competitiveness Models in Different Countries of the World, Especially in Balkan Region Destinations. European Journal of Multidisciplinary Studies Jan-Apr 2016 Vol.1 No. 1, p 58-63 (Online).

BETHAPUDI, ANAND (2013). The Role Of ICT In Tourism Industry, Journal Of Applied Economics And Business, Vol.1, Issue 4 - December, p. 67-79.

BLANKE, J AND CHIESA T (Eds) (2008). The Travel \& Tourism Competitiveness Index Report 2008: Meansuring Key Elements Driving The Sector's Development. World Economic Forum, p 3-26. Available at (Http://Www.Weforum.Org. (2013). The Travel \& Tourism Competitiveness Index Report. World Economic Forum p xvi. Available at: Http://Www.Weforum.Org.

BPS INDONESIA (2015). Statistik Indonesia. BPS Indonesia.

BPS MALUKU UTARA (2016). Maluku Utara Dalam Angka, SUSENAS, BPS Provinsi Maluku Utara.

BPS KOTA TERNATE (2016). Statistik Maluku Utara. BPS Kota Ternate.

CALDERON, C., L. SERVEN. (2004). The Effects of Infrastructure Development on Growth and Income Distribution. World Bank Policy Research Working Paper No. 3400. Washington, D.C.: World Bank.

CHIN, WEI LEE, JANET HADDOCK-FRASER \& MARK P. HAMPTON (2015). Destination Competitiveness: Evidence From Bali. Current Issues in Tourism, p.1-25. Available at: http://dx.doi.org/10.1080/13683500.2015.

CHIN, CHEE-HUA; MAY-CHIUN, LO; PETER. S AND VIKNESWARAN. N (2014). Rural tourism destination competitiveness: A Study on Annah Rais Longhouse Homestay, Sarawak. Procedia. Social and Behavioral Sciences 144 (2014) p 3544. Available at: www.sciencedirect.com. 
CROTTI, R AND TIFFANY M (2015). World Economic Forum The Travel \& Tourism Competitiveness Index: T\&T as a Resilient Contribution To National Development. World Economic Forum p.17, available at :Http://Www.Weforum.Org.

CROITORU, M (2011). Tourism Competitiveness Index -An Empirical Analysis Romania vs. Bulgaria. Theoretical and Applied Economics Volume XVIII (2011), No. 9(562), p. 155-172.

CROUCH. G.I, AND RITCHIE B.J.R. (1994). Destination competitive-exploring foundations for a long term research program, Proceedings of Administrative Sciences Association of canada 1994 Annual Conference, Halifax, Nova Scotia p.79-88.

, (1999), Tourism, competitiveness, and social prosperity, Jurnal Of Business research', Vol 44 No 3 p.137-152. Elsevier Science Inc.

DAMANIK, J (2013). Pariwisata Indonesia: Antara Peluang dan Tantangan. Yogyakarta: Pustaka Pelajar.

DAVID, FRED R. AND F. R. DAVID (2015). Strategic Management: A Competitive Advantage Approach, Concepts \& Cases, 15th Edition, Pearson Education, England.

EMZIR (2011). Metode Penelitian Kualitatif : Analisis Data. RajaGrafindo Persada. Jakarta.

FACCARELLO, G. (2016). Comparative Advantage. https://www.researchgate.net/publication.

GUZMÁN, T. L; SANDRA. S-CAÑIZARES AND VÍCTOR P. (2011). Community - Based Tourism In Developing Countries: A Case Study, Tourismos: An International Multidisciplinary Journal Of Tourism Volume 6, Number 1, Spring 2011, p. 6984.

GRACAN, D; ROMINA A. R AND SINISA B (2008). Restorable Energy Sources As A Factor Of The Competitive Improvement Ability Of A Tourist Destination. Tourism and Hospitality Management, Tourism And Hospitality Management, Vol. 14, No. 2, p. 217-228. Available at : Http://Www.Fthm.Hr/Index.Php?Option=Com.

GARCIA-MILÀ, T., T. MCGUIRE, R. PORTER (1996). The Effect of Public Capital in State-Level Production Functions Reconsidered," Review of Economics and Statistics 78 (1), p 177- 180.

GRAMLICH, E. M. (1994). Infrastructure Investment: A Review Essay. Journal of Economic Literature 32 (3), 11, p 76-96.

HAMARNEH, IVETA (2013). Jordan as a Tourist Destination. Jurnal Of Tourim and Services. Vysoká Škola Obchodní V Praze, O. P. S., Spálená 14, 11000 Prahal p 21-36. Available at: Www.Vso-Praha.Eu.

HUTTASIN, NARA; HANS. M AND LUUK. K (2015). Towards Tourism Development Of The Isan Region, Northeastern Thailand. IJAPS, Vol. 11, Supplement 1, p 103128.

INSKEEP, EDWAR (1991). Tourism Planing: An Integrated and Sustainable Developmen Approach. New York: Van Nostrand Reinhold.

JOVANOVIĆ, VERKA AND ANGELINA NJEGUŠ (2008). The Application Of Gis and Its Components In Tourism. Yugoslav. Journal of Operations Research Vol 18 (2008), Number 2, p. 261-272.

JOVICIC, DOBRICA AND VANJA IVANOVIC (2008). Enviromental Protection-Key Prerequisite For Sustainable Tourism On Mediterranean. Tourism And 
Hospitality Management. Tourism And Hospitality Management, Vol. 14, No. 2 , p. 217-228, available at : http://www.fthm.Hr/Index.Php? Option=Com.

KARINI, NI MADE OKA (2011). Pengelolaan Daya Tarik Wisata Tinggalan Arkeologi Yang Berkelanjutan Di Bali. Jurnal Analisis Pariwisata. Issn.1410-3729. Vol. 11 No. 1 Th. 2011, Hal. 1-7.

KEMENTRIAN PARIWISATA REPUBLIK INDONESIA (2014). Laporan Kinerja Kementrian Pariwisata Tahun 2014. KEMENPAR RI.

KIESSLING, T. AND M. HARVE (2005). Strategic Global Human Resource Management Research In The Twenty-First Century: An Endorsement Of The Mixed Method Research Methodology. The International Journal Of Human Resource Management, 16:1 January 2005, p 22-45. Available at: Http://Www.Tandf.Co.Uk/Journals.

KOVAČIĆ, M; ZVONKO. G AND DESIMIR. B (2011). Nautical Tourism In Fostering The Sustainable Development: A Case Study Of Croatia's Coast And Island, Tourismos: An International Multidisciplinary. Journal Of Tourism, Volume 6, Number 1, Spring 2011, p. 221-232.

KING, R. AND R. LEVINE. (1993). Finance, Entrepreneurship, and Growth. Journal of Monetary Economics 32 (3), p 513-542.

LANGDANA, F AND MURPHY, P.T (2014). International Trade and Global Macropolicy, Springer Texts in Business and Economics. Springer Science Business Media, New York. Availabele at: http://www.springer.com/978-1-4614-1634-0.

LEVINE, R. (2005). Law, Endowments, and Property Rights. Journal of Economic Perspectives 19 (3), p 61-88.

MARZUKI, A; ABDUL A; BADARUDDIN M; ABDUL G O; AHMAD P (2011). Assessment Of Nature-Based Tourism In South Kelantan, Malaysia. Tourismos: An International Multidisciplinary Journal Of Tourism. Volume 6, Number 1, Spring 2011, p. 281-295.

MEYER, BEATA (2012). Environmental Impacts Of The Development Of Brand Tourist Products In The West-Pomeranian Province. Scientific Journal No. 658 Economic Problems Of Tourism Vol. 1 (17), p. 251-261.

MIHALIC (2000). Environmental management of tourist destinations; a factors of tourist competitiveness. Tourism Management Vol 21 no 1, p 65-78.

MULJADI DAN WARMAN (2009). Kepariwisataan dan Perjalanan (Edisi revisi 2016), Rajagrafindo Persada, Jakarta.

MUHAMMAD, S (2013). Manajemen Strategik: Konsep dan Alat Analisis. (cet ke-5). Sekolah Tinggi Ilmu Manajemen. Yogyakarta.

MUKHTAR (2013). Metode Praktis Penelitian Dskriptif Kualitatif. Referensi, Jakarta Selatan.

OKECH, ROSELYNE NYAWIRI (2004). The Role of Tour Operators in Sustainable Ecotourism: Lessons from Kenya. Tourism Today: The Journal Of The College Of Tourism And Hotel Management. Number 4 Autumn 2004, P.78-88.

OTHMAN, PAZIM AND ROSLI, M. MOHD (2011). The Impact of Tourism on Small Business Performance: Empirical Evidence from Malaysian Islands. International Journal of Business and Social Science Vol. 2 No. 1; January 2011. p.11-21, available at : www.ijbssnet.com.

PORTER, MICHAEL E. (1980). Competitive Strategy: Techniques for Analyzing Industri and Competotors. Free Press. New York.

and Competitive Advantage: Creating and Sustaining Superior. Free Press, New York. 
(1990). The Competitive Advantage of Nations. The Free Pess, New York.

PRATIWI, F RATU, MOH K, AND SUSILO (2016). Shift Sector Analysis Of Economy In Mamminasata Region. International Journal Of Social And Local Economic Governance (IJLEG), Vol. 2, No. 2, October 2016, P 103-108: Available at: http://Ijleg.Ub.Ac.Id

PRASETYA, DIDIK DWI (2011). Aplikasi Virtual Tour Berbasis Web Sebagai Media Promosi Pariwisata. Seminar On Electrical, Informatics, and Its Education 2011. Hal.58-63.

PRAYOGI, PUTU AGUS (2011). Dampak Perkembangan Pariwisata di Objek Wisata Penglipuran, Jurnal Perhotelan dan Pariwisata, Sekolah Tinggi Pariwisata Triatma Jaya, Agustus 2011, Vol.1 No.1, hal.64-79.

RAJAN, R., L. ZINGALES (1998). Financial Dependence and Growth. American Economic Review 88 (3), p 559-586.

RPJMN INDONESIA (2015). Rencana Pembangunan Jangka Menengah Indonesia Periode 2015-2019. BAPPENAS, Indonesia.

RPJMD KOTA TERNATE (2011). Rencana Pembangunan Jangka Menengah Daerah Kota Ternate Periode 2011-2015. BAPPEDA Kota Ternate.

SEDARMAYANTI (2014). Manajemen Strategi. Refika Aditama, Bandung.

SCHUMACHER, REINHARD (2016). Adam Smith's theory of absolute advantage and the use of doxography in the history of economics. Erasmus Journal for Philosophy and Economics, Volume 5, Issue 2, Autumn 2012, p. 54-80. http://ejpe.org/pdf/52-art-3.pdf.

(2012). Free Trade and Absolute and Comparative Advantage: A Critical Comparison of Two Major Theories of International Trade. Zugl.: Potsdam, Univ., Diplomarbeit, 2012: http://pub.ub.unipotsdam.de/volltexte/2012/6023/).

SAFTIC, D; ANA TEŽAK; AND NINOSLAV. L (2011). Stakeholder Approach In Tourism Management: Implication In Croatian Tourism. International Conference On Organizational Science Development Future Organization.

SOTERIADES, MARIOS; CONSTANTIN A AND STELIOS V (2004). E-marketing and Ecommerce in the Tourism Industry: A Framework to Develop and Implement. Business Initiatives. The Journal Of The College Of Tourism and Hotel Management. Number 4 Autumn 2004, P.157-169.

SNIEŠKA, V.; BRUNECKIENE, J (2009). Measurement of Lithuanian Regions by Regional Competitiveness Index, Inzinerine Ekonomika - Engineering Economics (1): p 45-57.

STIPANOVIC, CHRISTIAN AND SUZANA. B (2008). The Development Design Model In The Competitiveness Of Intelligent Business Organisations. Tourism and Hospitality Management, Vol. 14, No. 2, Pp. 217-228, available at: Http://Www.Fthm.Hr/Index.Php?Option.

SURYADANA, M.L DAN OCTAVIA V (2015). Pengantar Pemasaran Pariwisata. Alfabeta, Bandung.

SUGIARTO, HENDRATONO, T DAN SUDIBYO, D (2015). Metodologi Penelitian Hospitaliti dan Pariwisata. Matana Publishing Utama, Tangerang.

SUGIYONO (2016). Metode Penelitian Kuantitatif, Kualitatif dan R\&D. Alvabeta, Bandung.

TARIGAN, ROBINSON (2014). Ekonomi Regional: Teori dan Aplikasi (Cet-7). PT. Bumi Aksara, Jakarta.

TATHAGATI AND INDSCRIPT (2015). Super Tourismpreneur: A-Z Inspirasi Bisnis dan Mengelola Bisnis Pariwisata. Andi Offset, Yogyakarta. 
VALLE, P OOM DO; JOÃO A. SILVA; JÚLIO. M AND MANUELA. G (2006). Tourist Satisfaction and Destination Loyalty intention: A Structural and Categorical Analysis. Journal of Business Science and Applied Management, Volume 1, Issue 1, p.25-44.

WU, C. LUNG AND HSIAO-MING C. (2013). Island Marine Tourism Development Critical Success Factors - Case by Wangan in Taiwan. The Journal of Global Business Management Volume 9, Number 3, October 2013, p. 126-135.

Word Economic Forum (WEF) (2015). The Travel \& Tourism Competitiveness Report. Available at: Http://Www.Weforum.Org.

WEF (2011). The Travel \& Tourism Competitiveness Report. Available at: Http://Www.Weforum.Org.

WEF (2013). The Travel \& Tourism Competitiveness Report. Available at: Http://Www.Weforum.Org.

World Tourism Organization (WTO) (2002). Tourism and Poverty Alleviation. Avalable at: http: //www.world tourism.org/liberalization/poverty /tourism.

XIN, T. KAI DAN JENNIFER K. L. C (2014). Tour operator perspectives on responsible tourism indicators of Kinabalu National Park, Sabah. Journal Procedia-Social and Behavioral Sciences, P 25 - 34, available at: www.sciencedirect.com.

YOETI, H. OKA (1996). Pemasaran Pariwisata Terpadu (edisi revisi 2013). Angkasa, Bandung.

ZAEI MANSOUR E DAN ZAEI, MAHIN E. (2013). The Impacts Of Tourism Industry On Host Community. European Journal Of Tourism Hospitality And Research Vol.1, No.2, p.12-21, available at : Www.Ea-Journals.Org. 